\title{
SimReg1 is a master switch for biosynthesis and export of simocyclinone D8 and its precursors
}

\author{
Liliya Horbal', Yuriy Rebets ${ }^{1}$, Mariya Rabyk ${ }^{1}$, Roman Makitrynskyy ${ }^{1}$, Andriy Luzhetskyy ${ }^{2}$, Victor Fedorenko ${ }^{1}$ and \\ Andreas Bechthold ${ }^{3 *}$
}

\begin{abstract}
Analysis of the simocyclinone biosynthesis (sim) gene cluster of Streptomyces antibioticus Tü6040 led to the identification of a putative pathway specific regulatory gene simReg1. In silico analysis places the SimReg1 protein in the OmpR-PhoB subfamily of response regulators. Gene replacement of simReg1 from the S. antibioticus chromosome completely abolishes simocyclinone production indicating that SimReg1 is a key regulator of simocyclinone biosynthesis. Results of the DNA-shift assays and reporter gene expression analysis are consistent with the idea that SimReg1 activates transcription of simocyclinone biosynthesis, transporter genes, regulatory gene simReg3 and his own transcription. The presence of extracts (simocyclinone) from S. antibioticus Tü6040 $\times$ pSSimR1-1 could dissociate SimReg1 from promoter regions. A preliminary model for regulation of simocyclinone biosynthesis and export is discussed.
\end{abstract}

Keywords: Simocyclinone, angucycline, regulation, transport

\section{Introduction}

The actinomycetes, including in particular members of the genus Streptomyces, are the industrial source for a large number of bioactive compounds employed as antibiotics and other drugs Horinouchi 2007; Bibb and Hesketh 2009. Actinomycetes produce these molecules as part of their "secondary" or nonessential metabolism van Wezel et al. 2009. Many Streptomyces species are capable of producing more than one secondary metabolite Ohnishi et al. 2008; van Wezel et al. 2009. The timing of the production of secondary metabolites and the amount of the accumulated compounds correlates with the environmental conditions and morphological differentiation van Wezel et al. 2009; Bibb et al. 2009; van Wezel et al. 2011. Furthermore, it has also been associated with the accumulation of small signaling molecules, such as ppGpp, microbial hormones, and late intermediates or end-products of the secondary metabolite biosynthetic pathways Ruiz et al. 2008; O'Rourke et al. 2009; Hsiao et al. 2009; Wang et al. 2009. The influence of all aforementioned factors in most cases is reflected to

\footnotetext{
* Correspondence: andreas.bechthold@pharmazie.uni-freiburg.de ${ }^{3}$ Institut für Pharmazeutische Wissenschaften, Lehrstuhl für Pharmazeutische Biologie und Biotechnologie, Albert-Ludwigs-Universität Freiburg, StefanMeier-Strasse 19, 79104 Freiburg, Germany

Full list of author information is available at the end of the article
}

the activity of the pathway-specific regulatory genes, which are believed to be final checkpoints in the onset of antibiotic production Arias et al. 1999; Nuria et al. 2007; van Wezel et al. 2009; Pulsawat et al. 2007; Wang et al. 2009. Because most antibiotics are potentially lethal to the producing organism, the onset of antibiotic production should be under tight control and mechanisms of selfresistance of producing bacteria must exist. All this requires a precise regulatory network coordinating both, biosynthesis and resistance genes expression Le et al. 2009. That is why very often resistance genes are linked to antibiotic biosynthesis genes Tahlan et al. 2007; Ostash et al. 2008. As our understanding of secondary metabolism advances, it is becoming clear that the relationship between antibiotic production and resistance is more complicated than expected. For example, in S. coelicolor, along with the mature antibiotic(s), intermediates of the biosynthetic pathway might activate expression of the export genes, thereby coupling resistance to biosynthesis Hopwood 2007. In S. cyanogenus intermediates are able, not only to release repression of the export machinery, but also to de-repress expression of the late biosynthetic enzymes that attach the final sugars to yield mature landomycin A Ostash et al. 2008. However, despite the identification and characterization of numerous genes, which 
affect antibiotic production and resistance, our understanding of the regulatory networks that govern these processes is far from complete.

A biosynthetic gene cluster usually contains at least one regulatory gene Sheldon et al. 2002; Rebets et al. 2003; Rebets et al. 2008; Chen et al. 2008. This is also the case for the gene cluster of the aminocoumarin antibiotic simocyclinone D8 (Figure 1), produced by S. antibioticus Tü6040, that has distinct cytostatic and antibiotic activities Trefzer et al. 2002; Galm et al. 2002; Oppegard et al. 2009; Sadig et al. 2010; Edwards et al. 2009. The simocyclinone biosynthetic gene cluster includes three putative regulatory genes: $\operatorname{simReg1}$, simReg2 (hereafter $\operatorname{sim} R$ ) and simReg3 (Figure 2). Recently, the function of SimR was investigated in vitro and it was shown to repress the transcription of $\operatorname{sim} X$ gene that encodes simocyclinone efflux pump Le et al. 2009; Le et al. 2011, whereas the function of the two other regulators is still unknown. SimReg1 is the first example of an OmpR-PhoB subfamily regulator, identified in an aminocoumarin biosynthetic gene cluster. Herein, we describe the generation and analysis of the mutant strain deficient in the simReg1 gene, mobility shift DNA-binding assays of His-SimReg1 to putative promoter regions and propose a putative model for regulation of the biosynthesis and export of simocyclinones.

\section{Materials and methods}

\section{Bacterial strains, plasmids, and culture conditions}

All strains and plasmids are listed in Table 1. E. coli DH5 $\alpha$ (Life Technologies) was used for routine subcloning. $E$. coli ET12567 harboring the conjugative plasmid pUB307 (provided by C. P. Smith, UMIST, Manchester, UK) was used to perform intergeneric conjugation from E. coli to Streptomyces species Flett et al. 1997; Luzhetskyy et al. 2006. For plasmid and total DNA isolation, E. coli and $S$. antibioticus strains were grown as described by Sambrook and Russell (2001), and Kieser et al. (2000). For simocyclinone production, S. antibioticus strains were grown in liquid NL5 medium $\left(\mathrm{NaCl} 1 \mathrm{~g} \mathrm{l}^{-1}, \mathrm{KH}_{2} \mathrm{PO}_{4}\right.$ $1 \mathrm{~g} \mathrm{l}^{-1}, \mathrm{MgSO} 4 \times 7 \mathrm{H}_{2} \mathrm{O} 0.5 \mathrm{~g} \mathrm{l}^{-1}$, glycerol $25 \mathrm{~g} \mathrm{l}^{-1}$, L-glutamin - 5.84 $\mathrm{g} \mathrm{l}^{-1}$, trace elements $-2.0 \mathrm{ml}$, pH 7.3 prior to sterilization) at $30^{\circ} \mathrm{C}$. For conjugation, spores of
S. antibioticus strains were harvested from a sporulated lawn grown on soya-mannitol or oatmeal medium Kieser et al. 2000Luzhetskyy et al. 2006. When it was necessary, bacterial strains were grown in the presence of respective antibiotics. X-gal and IPTG were used for blue-white colony selection in the case of the pBluescript, pSET152, pKC1139, pKC1218E vectors as described elsewhere Kieser et al., 2000; Sambrook et al., 2001.

\section{DNA manipulations}

Isolation of genomic DNA from streptomycetes and plasmid DNA from $E$. coli were carried out using standard protocols Kieser et al. 2000. Restriction enzymes and molecular biology reagents were used according to the recommendation of suppliers (NEB, MBI Fermentas, Promega). DIG DNA labeling and Southern hybridization analyses were performed according to the DIG DNA labeling and detection kit (Roche Applied Science).

\section{Construction of the plasmid for simReg1 inactivation}

A $4.3 \mathrm{~kb}$ BamHI fragment carrying the entire simReg1 gene and its flanking regions was cloned from 5JH10 (Table 1) into pUC19 to yield pUCsimR1 with an unique BsaAI site within the coding region of the simReg1 gene. The plasmid pUCsimR1 was digested with BsaAI and ligated to the hygromycin resistance cassette hyg, retrieved as an EcoRV fragment from pHYG1 (Table 1). The resulting plasmid pUCsimR1-hyg was digested with BamHI and the fragment containing the simReg1::hyg mutant allele was cloned into the shuttle vector pKC1139 to yield pKCsimR1-hyg.

\section{Generation of the chromosomal mutant S. antibioticus $\Delta$ simReg1}

The gene disruption plasmid pKCsimR1-hyg was conjugally transferred from E. coli into S. antibioticus Tü6040. Exconjugants were selected for resistance to apramycin $\left(10 \mu \mathrm{g} \mathrm{ml}^{-1}\right)$. To generate S. antibioticus $\Delta$ simReg1 strain, single-crossover mutants were obtained by cultivation of the respective exconjugants at $39^{\circ} \mathrm{C}$ for 3 days with a further screen for the loss of apramycin resistance as a consequence of a secondary crossover.

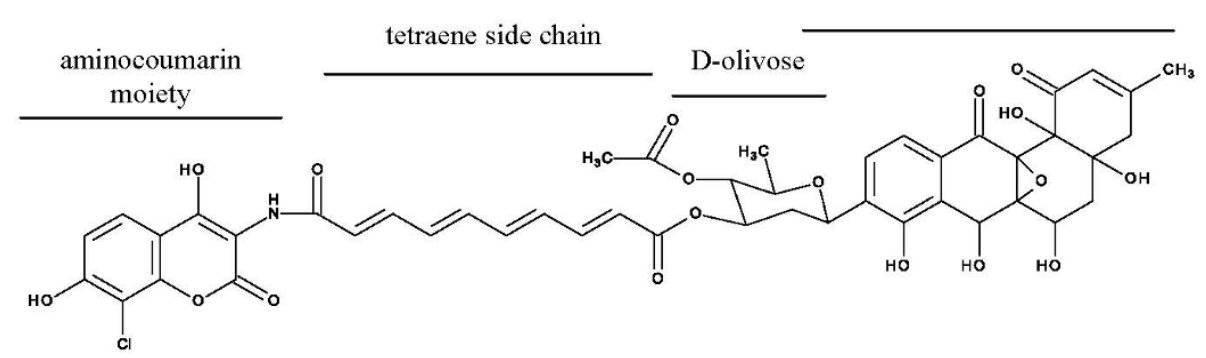

Figure 1 Structure of simocyclinone D8. 


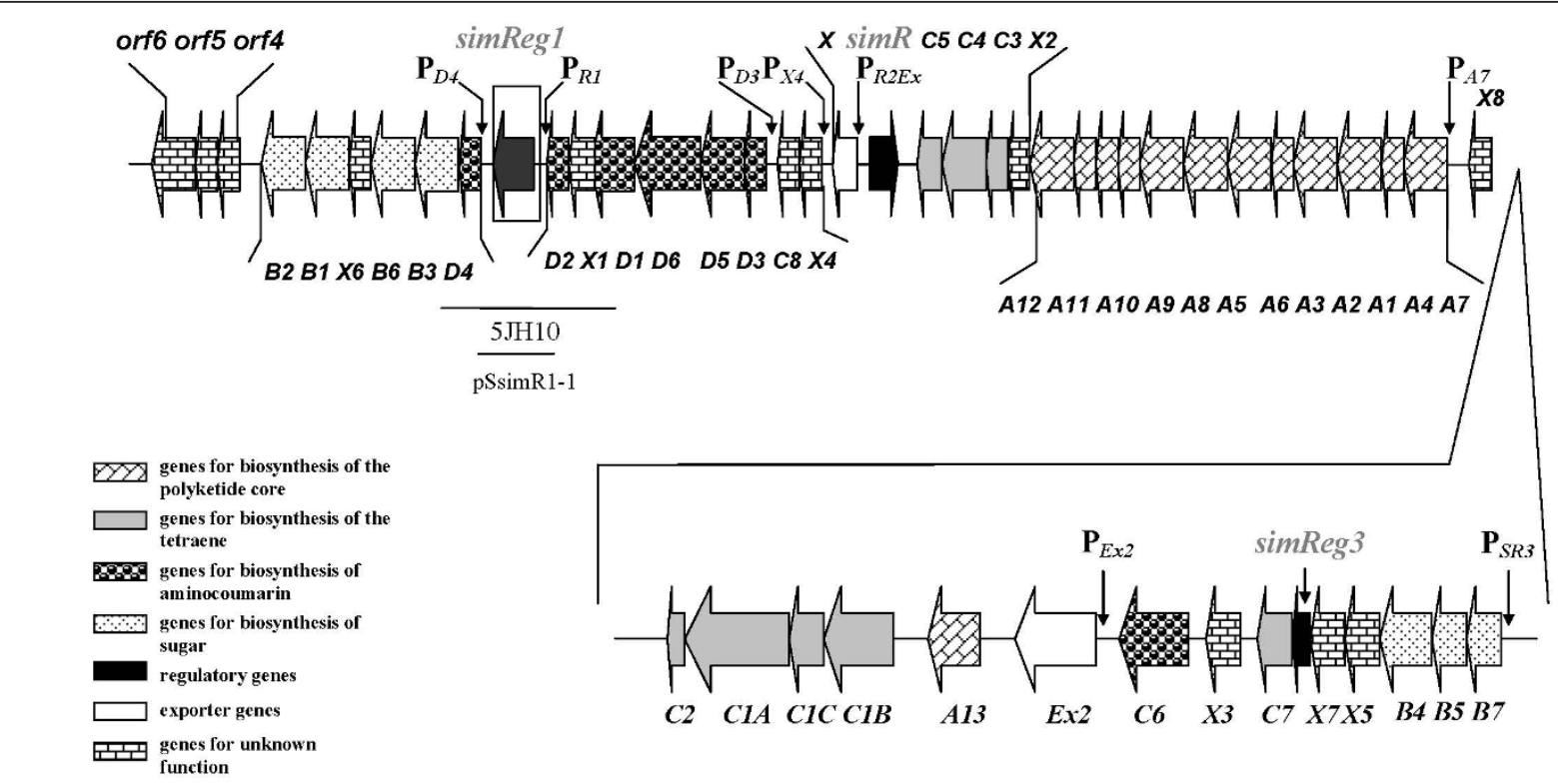

Figure 2 Schematic representation of the simocyclinone biosynthesis gene cluster (sim cluster) of S. antibioticus Tü6040. Fragments used for gene disruption and expression experiments are shown below the genes. Putative promoter regions are indicated with arrows.

\section{Complementation of the simReg1 mutant}

The simReg1 gene with flanking regions was retrieved from the plasmid pKCEsimR1 Rebets et al. 2008 as a 2.3 $\mathrm{kb}$ BamHI fragment and cloned into the BamHI sites of pSET152 to yield pSsimR1. A 1.4 kb SmaI fragment harboring only simReg1 with its promoter region was retrieved from pSsimR1 and cloned into EcoRV linearized pSET152 to yield pSsimR1-1.

\section{Construction of the plasmids for gusA reporter fusion system}

A $0.5 \mathrm{~kb}$ DNA fragment, containing promoter of the simD4 gene $\left(\mathrm{P}_{D 4}\right)$ was amplified from the chromosome S. antibioticus Tü6040 using primers simD4_for_script and simD4_rev_script (Table 2). The PCR product was digested with $\mathrm{XbaI} / \mathrm{KpnI}$ and cloned into the respective sites of pGUS Myronovskyi et al. 2011, giving pSimD4script. In this plasmid transcription of the gusA gene is under the control $\mathrm{P}_{S D 4}$ promoter.

A $0.8 \mathrm{~kb}$ fragment, carrying the simReg1 gene, was amplified from the $S$. antibioticus Tü6040 chromosome using the primers simReg1_for and simReg1_rev (Table 2 ). The amplified DNA fragment was cleaved with HindIII/BamHI and cloned into the respective sites of pUWL-oriT (Table 1), yielding pUWLsimReg1. In this plasmid the simReg1 gene is under the control of $\mathrm{P}_{\text {ermE }}$.

\section{Spectrophotometric measurement of glucuronidase activity in cell lysates}

For measurement of GusA activity, mycelium of the S. lividans strain harboring both pSimD4script and
pUWLsimReg1 plasmids, the control strains S. lividans $1326 \times$ pSimD4script, S. lividans $1326 \times$ pGUS, and S. lividans $1326 \times$ pGUS/pUWLsimReg1 were grown in liquid TSB medium $(100 \mathrm{ml})$ for 2 days at $30^{\circ} \mathrm{C}$ in a rotary shaker $(180 \mathrm{rpm}) .1 \mathrm{ml}$ of the pre-culture was inoculated into liquid TSB medium $(100 \mathrm{ml})$ and grown for 5 days at $30^{\circ} \mathrm{C}$ in a rotary shaker. Mycelium was harvested, washed with distilled water, then resuspended in lysis buffer (50 mM phosphate buffer [pH 7.0], 0.1\% Triton X-100, $5 \mathrm{mM} \mathrm{DTT}, 4 \mathrm{mg} \mathrm{ml}^{-1}$ lysozyme) and incubated for $30 \mathrm{~min}$ at $37^{\circ} \mathrm{C}$. Lysates were centrifuged for $10 \mathrm{~min}$ at $5000 \mathrm{rpm}$. Then, $0.5 \mathrm{ml}$ of lysate was mixed with $0.5 \mathrm{ml}$ of dilution buffer $(50 \mathrm{mM}$ phosphate buffer [pH 7.0], 5 mM DTT, 0.1\% Triton X-100) supplemented with $5 \mu \mathrm{l} 0.2 \mathrm{M} p$-nitrophenyl- $\beta$-D-glucuronide and used for measuring optical density at $\lambda=415 \mathrm{~nm}$ every minute during $20 \mathrm{~min}$ of incubation at $37^{\circ} \mathrm{C}$. As a reference, a 1:1 mixture of lysate and dilution buffer was used.

\section{Analysis of secondary metabolites production}

Streptomyces strains were grown in liquid TSB medium $(50 \mathrm{ml})$ for 2 days at $30^{\circ} \mathrm{C}$ in a rotary shaker $(180 \mathrm{rpm})$. Five $\mathrm{ml}$ of the pre-cultures were inoculated into liquid NL5 medium $(100 \mathrm{ml})$ and the cultures were grown for 5 days at $30^{\circ} \mathrm{C}$ in a rotary shaker. The culture broths were extracted three times with $100 \mathrm{ml}$ of ethyl acetate. The extracts were dried in vacuum and dissolved in methanol $(200-400 \mu \mathrm{l})$. The metabolites were analyzed by high-pressure liquid chromatography-mass spectrometry (HPLC-MS) Schimana et al. 2001. $10 \mathrm{ml}$ of each culture 
Table 1 Strains and plasmids

\begin{tabular}{|c|c|c|}
\hline $\begin{array}{l}\text { Bacterial strains and } \\
\text { plasmids }\end{array}$ & Description & Source or reference \\
\hline E. coli DH5 $\alpha$ & supE44 $\operatorname{NacU169(\phi 80lacZMM15)}$ & Hanahan 1985 \\
\hline E. coli BL21 (DE3) pLysS & Host for the heterologous expression of His 6 -tagged simReg 1 & Novagen \\
\hline E. coli ET12567/pUB307 & $\begin{array}{l}\text { hsdR17 recAlendA1gyrA96 thi-1 relA1 dam-13::Tn9(Cmr) dcm-6 hsdM; harbors conjugative plasmid } \\
\text { pUB307; } \mathrm{Cm}^{r}, \mathrm{Km}^{r}\end{array}$ & Flett et al. 1997 \\
\hline S. antibioticus Tü6040 & Simocyclinone D8 producing strain & Trefzer et al. 2002 \\
\hline S. antibioticus & Derivative of S. antibioticus Tü6040 with & This work \\
\hline$\Delta \operatorname{sim} R e g 1$ & disrupted simRegl gene & \\
\hline $\begin{array}{l}\text { S. antibioticus } \Delta \text { simReg } 1 \times \\
\quad \operatorname{pSSimR1-1}\end{array}$ & $\begin{array}{c}\Delta \text { simReg1 strain carrying plasmid with the intact simReg1 gene under its own promoter, used for } \\
\text { complementation studies }\end{array}$ & This work \\
\hline S. lividans 1326 & Wild type & Hopwood et al. 1985 \\
\hline S. lividans $\times$ pSimD4script & $\begin{array}{c}\text { Derivative of S. lividans } 1326 \text { carrying plasmid with gusA gene under the control of the putative } \\
\text { promoter of the simD } 4 \text { gene }\end{array}$ & This work \\
\hline $\begin{array}{l}\text { S. lividans } \times \text { pSimD4script/ } \\
\text { pUWLsimReg1 }\end{array}$ & $\begin{array}{l}\text { Derivative of S. lividans } 1326 \text { carrying plasmid with gusA gene under the control of putative } \\
\text { promoter of the simD4 gene and second plasmid with simRegl gene under the control of } P_{\text {ermE }}\end{array}$ & This work \\
\hline S. lividans $\times$ pGUS & Derivative of S. lividans 1326 carrying plasmid with promoterless reporter gene gusA & This work \\
\hline $\begin{array}{l}\text { S. lividans } \times \text { pGUS/ } \\
\text { pUWLsimReg1 }\end{array}$ & $\begin{array}{c}\text { Derivative of S. lividans } 1326 \text { carrying plasmid with promoterless reporter gene gusA and plasmid } \\
\text { with simRegl gene under the control of the } P_{\text {ermE }} \text { promoter }\end{array}$ & This work \\
\hline pBluescriptllKS ${ }^{+}$ & General purpose cloning vector; $A p^{r}$ & MBI Fermentas \\
\hline pUC19 & General purpose cloning vector; $A p^{r}$ & MBI Fermentas \\
\hline pSET152 & E. coli/Streptomyces shuttle vector with $\phi \mathrm{C} 31$ integration system for streptomycetes; $\mathrm{Am}^{\mathrm{r}}$ & Bierman et al. 1992 \\
\hline pKC1218E & pKC1218 derivative expression vector with $\mathrm{P}_{\text {ermE }}$ promoter and SCP2* replicon; $\mathrm{Am}^{r}$ & Ostash et al. 2004 \\
\hline pHYG1 & pLitmus38 containing hygromycin resistance cassette hyg & $\begin{array}{l}\text { C. Olano Univ. de } \\
\text { Oviedo, Spain }\end{array}$ \\
\hline pKC1139 & E. coli/Streptomyces shuttle vector with temperature sensitive replicon pSG5, Am ${ }^{r}$ & Muth et al. 1989 \\
\hline pUWL-oriT & pUWL-KS derivative harboring oriT from pSET152 & Zelyas et al. 2009 \\
\hline pET21d & Vector for His-tagged protein expression & Novagen \\
\hline $5 \mathrm{JH} 10$ & pUC plus simB3-D4 segment & Trefzer et al. 2002 \\
\hline pUCsimR1 & pUC19 derivative containing simRegl gene & This work \\
\hline pUCsimR1-hyg & pUCsimR1 derivative with hyg cassette cloned into the simReg1 coding region & This work \\
\hline pKCsimR1-hyg & pKC1139 derivative with cloned simReg1::hyg construction used for simReg1 gene inactivation & This work \\
\hline pKCEsimR1 & pKCE1218 derivative containing simReg1 gene under the control of $P_{\text {ermE }}$ & Rebets et al. 2008 \\
\hline pSSimR1 & pSET152 plus $2.3 \mathrm{~kb}$ simD4-X1 segment & This work \\
\hline pSSimR1-1 & PSET152 derivative containing simReg1 gene under the control of its own promoter & This work \\
\hline pMA-simR1 & plasmid containing synthetic codon-optimized simRegl gene & Mr. Gene, Heidelberg \\
\hline pETSR1c-15 & pET21d derivative containing synthetic codon-optimized simReg1 gene & This work \\
\hline pGUS & pSET152 derivative containing promoterless reporter gene gusA & $\begin{array}{l}\text { Myronovskyi et } \\
\text { al.2011 }\end{array}$ \\
\hline pSimD4script & derivative of pGUS harboring gusA reporter gene under the promoter of the simD4 gene & This work \\
\hline pUWLsimReg1 & derivative of pUWL containing gene simReg1 under the control of $\mathrm{P}_{\text {ermE }}$ & This work \\
\hline
\end{tabular}

were taken and lyophilized. The dry weight of each sample was measured. In all cases amounts of antibiotic were referred back to equal amounts of biomass (dry weight) and are mean values from at least three independent experiments.

\section{Overexpression of SimReg1}

The codon-optimized copy of the simReg1 gene, named simReg1s, was synthesized by Mr. GENE Company (Heidelberg, Germany) and was provided on the plasmid pMA-simR1. Gene simReg1s was amplified from pMAsimR1 using primers SSR1F and SSR1R (Table 2). The
PCR product was cloned into the pET21d NcoI-EcoRI sites, giving pETSR1c-15.

E. coli BL21(DE3) (pLysS) harboring the pETSR1c-15 plasmid was grown overnight at $37^{\circ} \mathrm{C}$. LB $(400 \mathrm{~mL})$ containing $50 \mu \mathrm{g} / \mathrm{mL}$ of ampicillin was inoculated with $2 \mathrm{~mL}$ of the overnight culture and incubated at $21^{\circ} \mathrm{C}$ until the $\mathrm{OD}_{600 \mathrm{~nm}}$ reached 0.7. SimReg1 expression was induced with $1 \mathrm{mM}$ IPTG. After incubation for an additional 16 $\mathrm{h}$, the cells were harvested by centrifugation and washed with ice-cold column buffer (20 mM Tris- $\mathrm{HCl}[\mathrm{pH} 8.0]$, $50 \mathrm{mM} \mathrm{NaCl}$ ). Cell lysis and purification of SimReg1 with His-tag-binding resins were performed according to 
Table 2 Primers used in this study

\begin{tabular}{|c|c|c|c|}
\hline Primer & Nucleotide sequence $\left(5^{\prime}-3^{\prime}\right)$ & Purpose & Gene name \\
\hline SSR1F & ATACCATGGCCCGTGAACGT & SimReg 1 & simReg1 \\
\hline SSR1R & TTTGAATTCATTAATGGTGATGGT & purification & \\
\hline SR1D4F & TAGAATTCGTGAGCAGATCATGT & DNA-shift assay & $P_{D 4}$ \\
\hline SR1D4R & TAGAATTCCATTGTGAACCATC & & \\
\hline SD2R1F & TAGAATTCATCGCCACGACCATG & DNA-shift assay & $P_{R 1}$ \\
\hline SD2R1R & TAGAATTCCGCGGTTCGGCAGA & & \\
\hline $\operatorname{sim} \times 5 D 3 F$ & TAGAATTCTGTACAAGGCCTGGT & DNA-shift assay & $P_{D 3}$ \\
\hline $\operatorname{sim} \times 5 D 3 R$ & TAGAATTCGCGACAGGAGCCATA & & \\
\hline simEXX4F & TAGAATTCGACGCCTTCCAGTC & DNA-shift assay & $P_{X 4}$ \\
\hline $\operatorname{sim} E X X 4 R$ & TAGAATTCTCAGAACATCGTCC & & \\
\hline SR2EXXF & AAATCTAGATCAAGCCAGTGCTG & DNA-shift assay & $P_{\text {R2EX }}$ \\
\hline SR2EXXR & TITGAATTCTTGACCACCACTTC & & \\
\hline PSR2F & TCGACGAGGTCCTCTTTG & DNA-shift assay & $P_{S R 2}$ \\
\hline PSR2R & TCGTATTCATACACCGTAC & & \\
\hline PEx1F & CCAATTGCGCTACGCTCCT & DNA-shift assay & $P_{S E x 1}$ \\
\hline PEx1R & CCATGTAGGCGGTGACGA & & \\
\hline $\operatorname{sim} A 7 F$ & TAAAGCTTCAAAACGGGGTGAAC & DNA-shift assay & $P_{A 7}$ \\
\hline $\operatorname{sim} A 7 R$ & ATAAGCTTGTCGATACCGATCTTC & & \\
\hline PEX2F & ACTTCCCAGAAGTA & DNA-shift assay & $P_{E \times 2}$ \\
\hline PEX2R & AGAGGGCAGTAGAC & & \\
\hline PR3F & TITCTAGATGCACCCGATCCTC & DNA-shift assay & $P_{S R 3}$ \\
\hline PR3R & GAACAGGATTCGCATGAGTACT & & \\
\hline D4For & TATTGGTCGCGCAGTCGTCC & DNA-shift assay & part of the simD4 gene \\
\hline D4Rev & TTGTCCTGCATCATGACGAG & & \\
\hline simD4_for_script & $\begin{array}{c}\text { AAATCTAGAGGCGACCGACCCCG } \\
\text { GCCGAG }\end{array}$ & simD4 promoter cloning & $P_{D 4}$ \\
\hline simD4_rev_script & $\begin{array}{c}\text { AAAGGTACCCGATCCGGCTGGCA } \\
\text { TTACTG }\end{array}$ & & \\
\hline simReg1_for & $\begin{array}{c}\text { AAAAAGCTTTACCTGTATCCAGGGC } \\
\text { GGGCACTT }\end{array}$ & simReg1 cloning & simReg1 \\
\hline simReg1_rev & $\begin{array}{c}\text { AAAGGATCCGCACAAAGCGGCAGC } \\
\text { AATCG }\end{array}$ & & \\
\hline
\end{tabular}

Novagen instructions. SimReg1 was eluted with column buffer containing $200 \mathrm{mM}$ imidazole. The purest fractions (as determined by SDS-PAGE and Coomassie blue staining) were pooled, washed with storage buffer (50 $\mathrm{mM}$ potassium phosphate [pH 8.0], $300 \mathrm{mM} \mathrm{NaCl}, 10 \%$ glycerol), concentrated using Amicon Ultra (Millipore). Aliquots of SimReg1 fusion protein in storage buffer were stored at $-80^{\circ} \mathrm{C}$, or used immediately in DNA-binding assays.

Electrophoretic mobility shift DNA-binding assays (EMSA) DNA fragments containing putative promoters of $\operatorname{simD} 4$ ( $\left.\mathrm{P}_{D 4}, 513 \mathrm{bp}\right)$, simReg1 ( $\left.\mathrm{P}_{R 1}, 490 \mathrm{bp}\right), \operatorname{simD} 3\left(\mathrm{P}_{D 3}, 300 \mathrm{bp}\right)$, $\operatorname{sim} X 4\left(\mathrm{P}_{X 4}, 350 \mathrm{bp}\right), \operatorname{sim} A 7\left(\mathrm{P}_{A 7}, 300 \mathrm{bp}\right), \operatorname{sim} E x 2\left(\mathrm{P}_{E x 2}\right.$, $550 \mathrm{bp}), \operatorname{sim} B 7\left(\mathrm{P}_{S R 3}, 319 \mathrm{bp}\right), \operatorname{sim} X\left(\mathrm{P}_{\text {SEx1 }}, 280 \mathrm{bp}\right), \operatorname{sim} R$ $\left(\mathrm{P}_{S R 2}, 300 \mathrm{bp}\right)$, and the putative promoter region between $\operatorname{sim} X$ and $\operatorname{sim} R$ genes $\left(\mathrm{P}_{R 2 E x}, 780 \mathrm{bp}\right)$ (Figure 2) were used in EMSA. Indicated promoter regions were amplified from the chromosomal DNA of S. antibioticus using primer pairs listed in Table 2. Each EMSA contained $50 \mathrm{ng}$ of a target DNA and $0.9 \mu \mathrm{g}, 1.8 \mu \mathrm{g}, 2.7 \mu \mathrm{g}, 3.6 \mu \mathrm{g}, 4.5 \mu \mathrm{g}$ of the His-SimReg1 protein in a total volume of $20 \mu \mathrm{L}$ in a binding buffer (20 mM Tris $\mathrm{HCl}$ [pH 8.0], 1 mM EDTA, $1 \mathrm{mM}$ DTT, $100 \mathrm{mM} \mathrm{KCl}, 1 \mathrm{mM} \mathrm{MgCl} 2,10 \%$ glycerol). After incubation for $25 \mathrm{~min}$ at room temperature, protein-bound and free DNA were separated by electrophoresis at $4^{\circ} \mathrm{C}$ on a $4.5 \%$ nondenaturing polyacrylamide gel in $0.5 \times$ TBE buffer. The gel was stained with ethidium bromide and analyzed using a UV-imaging system (Fluorochem 5330). A negative control assay was carried out in the presence of the part of the simD4 coding region, amplified with the use of primers D4For and D4Rev (Table 2). Extracts from the strain S. antibioticus Tü6040 × pSsimR1-1, containing more then $95 \%$ of simocyclinones (Additional file 1), dissolved in methanol (5\% and $10 \%$ - final volume in a reaction mixture) were tested as SimReg1 ligands. 


\section{Results}

In silico analysis of the simReg1 gene product

The putative product of the simReg1 gene is a 251 aa protein with a molecular mass $27.94 \mathrm{kDa}$. As evident from BLAST and CDD search results, putative amino acid sequence of the protein has significant similarity to response regulators in two component control systems. The closest homologues of SimReg1 are proteins that act as positive regulators for angucycline-like biosynthesis, including JadR1 from S. venezuelae (60\% similarity) Wang et al. 2009, LanI from S. cyanogenus (58\% similarity) Rebets et al. 2008 and LndI from S. globisporus (58\% similarity) Rebets et al. 2003; Rebets et al. 2005. Analysis of the SimReg1 amino acid sequence using ExPASy Proteomics Server http://expasy.org revealed a putative signal receiver domain (the REC domain, aa 15-123) located at the Nterminal part of the protein and a DNA-binding domain at the C-terminus (aa 167-239). The latter is predicted to interact with short conserved regions of the target DNA and with the RNA polymerase. The secondary structure of the C-terminal DNA-binding domain of SimReg1 was similar to that of OmpR (E. coli) and PhoB (E. coli), which adopt a winged helix-turn-helix $(\mathrm{HTH})$ moiety. In the REC domain of the regulatory protein $\mathrm{PhoB}$, six conserved amino acid residues are believed to be vital for phosphorylation and consequence response Sola-Landa et al. 2003; Wang et al. 2009; Dyer and Dahlquist 2006, but only three of them are present in SimReg1 (Figure 3). Also, no protein kinase encoding genes have been found within the sim cluster. Thus, we suppose that SimReg1 belongs to "atypical" response regulators (ARR), like its close homolog JadR1 Wang et al. 2009.

\section{S. antibioticus $\Delta$ simReg1 mutant is deficient in simocyclinone production}

In order to investigate the function of simReg1, the chromosomal copy of the gene was replaced by the mutant allele containing a hygromycin resistance cassette ( $h y g)$ (Figure 4a). Inactivation of the simReg1 gene was proven by Southern hybridization. BamHI digested chromosomal DNA of the wild type and S. antibioticus $\Delta$ simReg1 strains were probed with the DIG-labeled fragment containing simReg1, obtained as a KpnI fragment from the plasmid pKCEsimR1 Rebets et al. 2008. A single hybridization signal of the expected size $(4.3 \mathrm{~kb})$ was detected in the case of the wild type strain and a $6.3 \mathrm{~kb}$ fragment was detected in the $\Delta$ simReg1 mutant (Figure $4 \mathrm{~b}$ ). The $S$. antibioticus $\Delta$ simReg1 mutant had growth and morphological characteristics identical to those of the wild type. HPLC and TLC analysis (Figure 5a) of the extracts from the mutant strain $\Delta$ simReg1 revealed no simocyclinone and its precursors, indicating that this gene is essential for antibiotic production.
To exclude any possibility of polar effects and to confirm that the cessation of simocyclinone production was caused

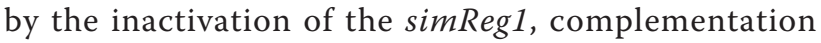
experiment was carried. For this purpose, we used the pSSimR1-1 plasmid (Table 1), which contains the simReg1 gene under its own promoter cloned in the integrative vector pSET152. This plasmid was transferred into $S$. antibioticus wild type strain by means of conjugation. The recombinant strain $S$. antibioticus $\Delta \operatorname{simReg1} \times \mathrm{pSSimR1-1}$ was found to accumulate simocyclinone at a level comparable to those of the wild type (Figure $5 b$ ).

It is known that very often overexpression of the positive pathway-specific regulators lead to overproduction of antibiotics (Bibb 2005; Novakova et al., 2011). To analyze the effect of additional copies of simReg1 gene on simocyclinone biosynthesis, we introduced the plasmid pSsimR1-1 that contains simReg1 gene under its own promoter, into the wild type strain. Recombinant strain S. antibioticus Tü6040 $\times$ pSSimR1-1 produced in average 2.5 times more simocyclinone then the wild type.

\section{SimReg 1 binds to the putative promoter regions of structural, transporter genes and its own gene}

In order to prove the DNA binding activity of SimReg1, gel mobility-shift assays were carried out. His-SimReg1 was purified (Additional file 2) and an in vitro binding assay was performed using His-SimReg1 and DNA fragments containing putative promoters of the regulator gene simReg1 $\left(\mathrm{P}_{R 1}\right)$, the 3 -keto-acyl-reductase gene simD4 $\left(\mathrm{P}_{D 4}\right)$, the oxygenase gene $\operatorname{sim} A 7\left(\mathrm{P}_{A 7}\right)$, the transporter gene $\operatorname{sim} E x 2\left(\mathrm{P}_{E x 2}\right)$, the 3-keto-acyl-reductase gene $\operatorname{sim} D 3$ $\left(\mathrm{P}_{D 3}\right)$, the putative gene $\operatorname{sim} X 4\left(\mathrm{P}_{X 4}\right)$, the putative olivosyltransferase gene $\operatorname{sim} B 7\left(\mathrm{P}_{S R 3}\right)$, and the intergenic region between $\operatorname{sim} R$ and the transporter gene $\operatorname{simEx1}$ (hereafter $\operatorname{sim} X)\left(\mathrm{P}_{R 2 E x}\right)$ (Figure 2). Shifted bands were detected using the promoter regions of the enzyme encoding genes (Figure 6a, c, d, f), the transporter gene simEx2 (Figure 6g) and the regulatory gene $\operatorname{simReg} 3$, which is likely co-transcribed with the genes $\operatorname{sim} B 7, \operatorname{sim} B 5, \operatorname{sim} B 4, \operatorname{sim} X 5$ and $\operatorname{sim} X 7$ (Figure 6h). Furthermore, DNA retardation occurred (Figure 6b) when the promoter of the simReg1 gene was used in the binding assay, indicating that SimReg1 is an autoregulatory protein. We carried out a set of control assays to demonstrate the specificity of the SimReg1 binding. For instance, none of the compounds in the crude extract of $E$. coli BL21(DE3) binds to any of the putative promoters (data not shown). We also showed that randomly chosen DNA did not interact with SimReg1 (Additional file 3).

SimReg1 was found to bind to the DNA fragment containing the $\operatorname{simR} / \operatorname{sim} X$ intergenic region (Figure 6e). However, it was not known whether SimReg1 interacts with the promoters of both genes. A $67 \mathrm{bp}$ fragment 


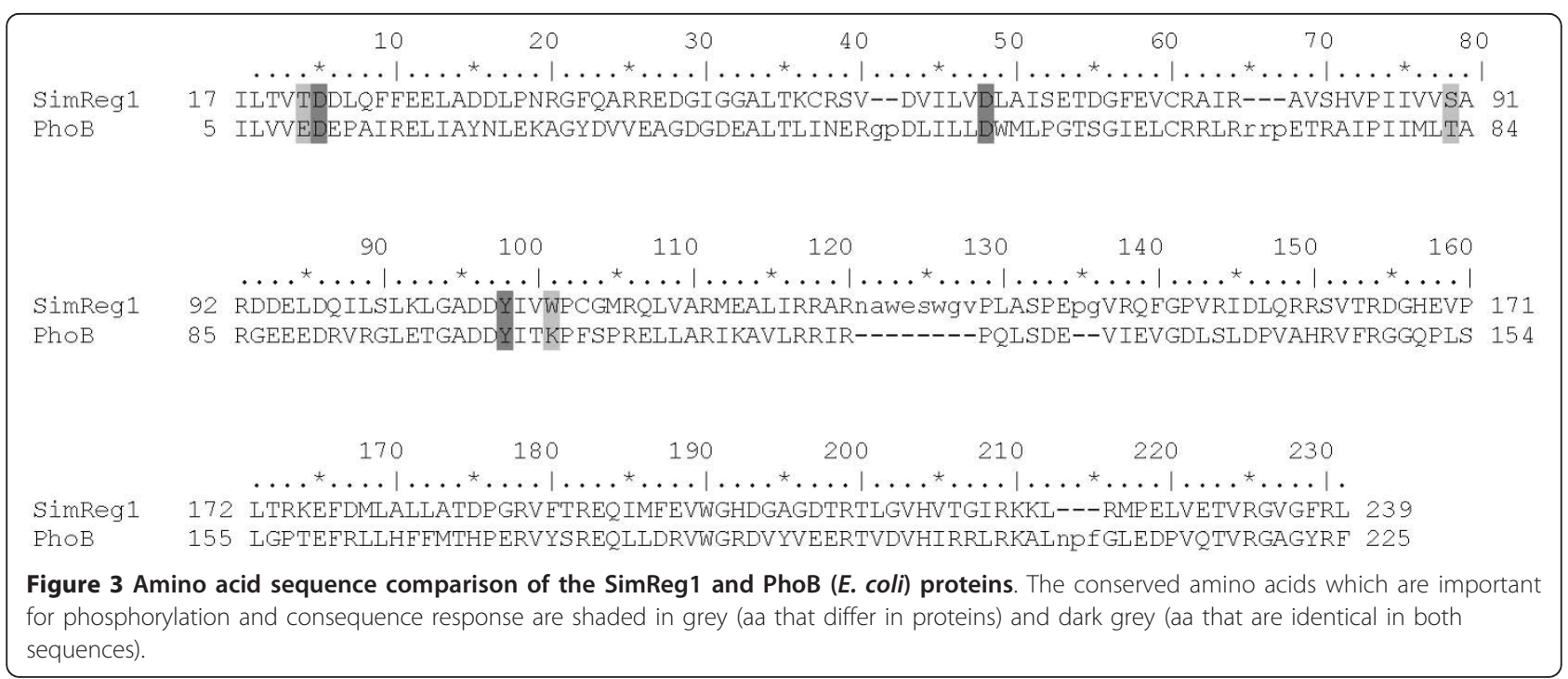

located in front of the start codon of $\operatorname{sim} R\left(\mathrm{P}_{S R 2}\right)$ and a $69 \mathrm{bp}$ fragment located in front of $\operatorname{sim} X\left(\mathrm{P}_{S E x 1}\right)$ (Figure 7a) were used for additional EMSA analysis. No binding was identified with the $\mathrm{P}_{S R 2}$ promoter, whereas DNA retardation occurred when the $\mathrm{P}_{S E x 1}$ promoter was used in the assay (Figure 7b). These results indicate that SimReg1 is capable of binding to the promoter region of $\operatorname{sim} X$.
Effect of culture extracts from S. antibioticus Tü6040 $\times$ pSSimR1-1 on the activity of SimReg1

Since DNA binding ability of JadR1, which also belongs to ARR and is very similar to SimReg1 (60\% similarity), is regulated by jadomycin B Wang et al. 2009, we studied the effects of simocyclinone extracts from the S. antibioticus Tü6040 $\times$ pSSimR1-1 on the DNA binding activity of SimReg1. For this purpose the culture broth of S. antibioticus (a)

Chromosome of

S. antibioticus Tü6040

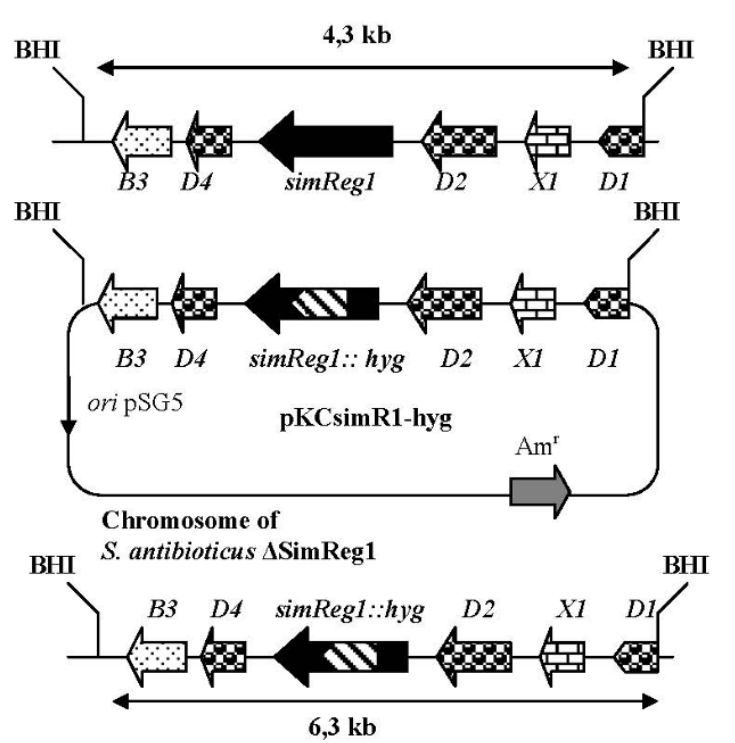

(b)

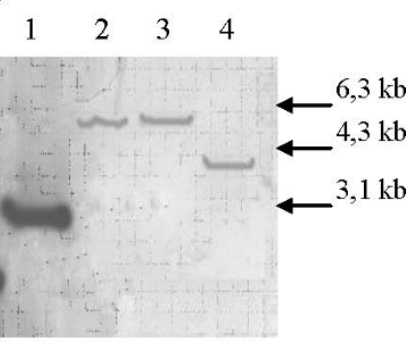

Figure 4 Inactivation of the simReg1 gene. (a) Schematic representation of the simReg1 gene disruption. (b) Results of the Southern
hybridization of Kpnl-digested plasmid pKCEsimR1 (1), BamHI digested total DNA samples from S. antibioticus $\Delta$ simReg1 (2, 3) and Tü6040 (4) with $1.4 \mathrm{~kb}$ Smal fragment harboring simReg1 gene. 


\section{a}

\section{simocyclinone}

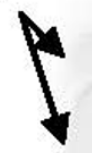

\section{b}

\section{simocyclinone}

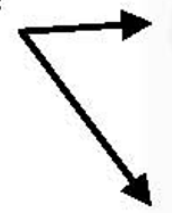

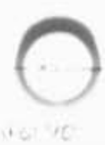

1

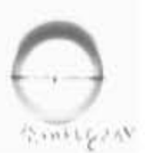

2

Figure 5 TLC analysis of secondary metabolites produced by: (a) S. antibioticus Tü6040 (1), $\Delta$ simReg1 (2) strains; (b) S. antibioticus Tü6040 (1), Tü6040 × pSSimR1-1 (2).

Tü6040 × pSSimR1 strain grown for 72 hours was extracted with an ethyl acetate, dried and dissolved in methanol. In overall the percentage of different types of simocyclinone in such an extract was more than $95 \%$ (Additional file 1). Presence of these extracts could dissociate His-SimReg1 from the promoter regions $\mathrm{P}_{R 1}$ and $\mathrm{P}_{A 7}$, as a result no shifted bands occurred (Figure 8 ). This effect was not due to methanol, the simocyclinone D8 solvent, as equivalent amounts of methanol had no effect on His-SimReg1-DNA complex formation (Figure 8).

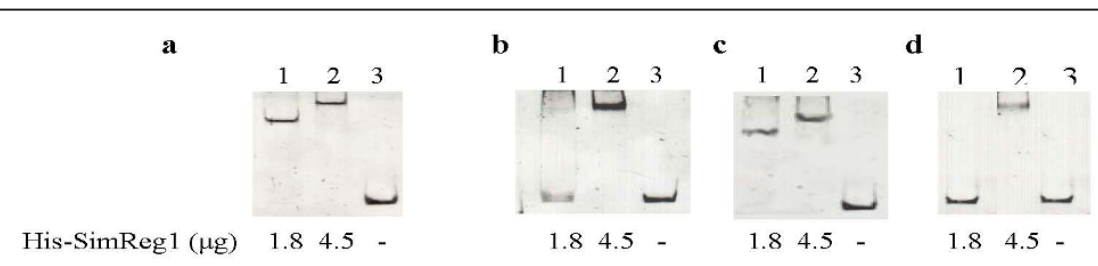

e
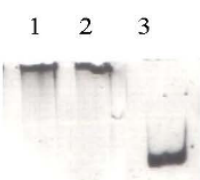

His-SimReg1 ( $\mu \mathrm{g}) \quad 1.8 \quad 4.5$ f

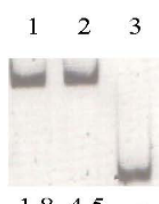

$\mathbf{g}$

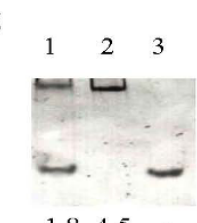

h

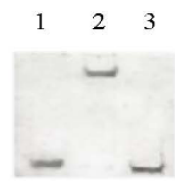

$1.84 .5 \quad-$

Figure 6 Results of an EMSA performed to detect interactions of His-SimReg1 to promoter regions of the sim cluster. In "a" promoter $P_{D 4}$ was used, in "b" $P_{R 1}$, in "c $c$ " $P_{D 3}$, in "d" $P_{X 4}$, in "e" $P_{R 2 E x,}$ in "f" $P_{A 7}$, in " $g$ " $P_{E X 2}$, and in " $h$ " $P_{S R 3}$. 


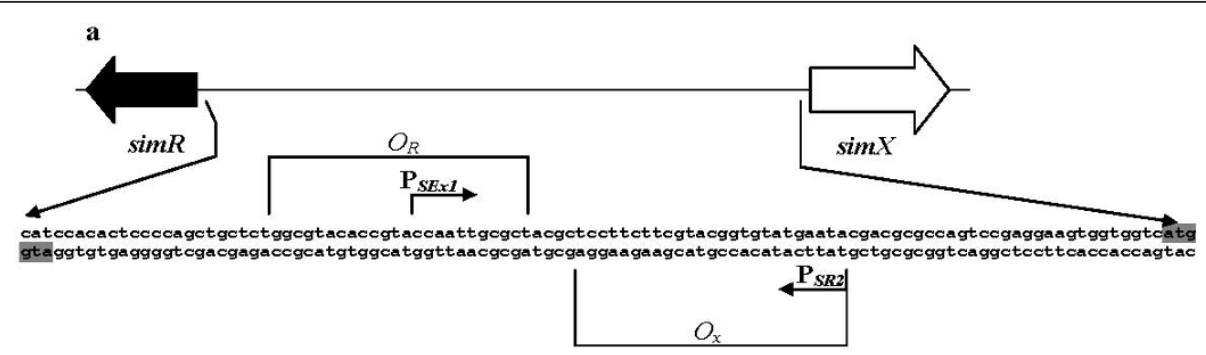

b

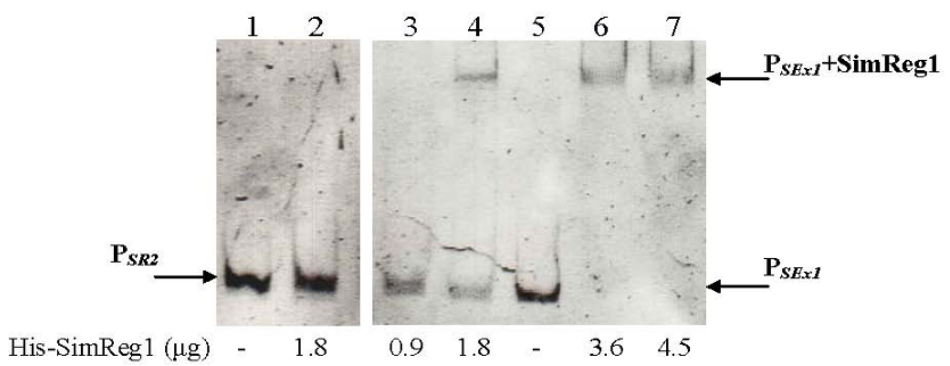

Figure 7 Results of EMSA performed to detect interactions of His-SimReg1 to $\mathbf{P}_{S R 2}$ and $\mathbf{P}_{S E x 1}$. (a) Schematic representation of the intergenic region between $\operatorname{sim} R$ and $\operatorname{sim} X$. Operators $O_{X}$ and $O_{R}$ are also shown (according to Le et al. 2009). Translation start codons are highlighted in dark grey. $P_{S R 2}$ and $P_{S E x 1}$ - indicate putative promoter regions used in EMSA. (b) Lane 1: $P_{S R 2 i}$ lane 2: $P_{S R 2}+$ His-SimReg1; lane 3:

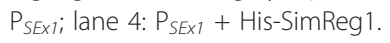

\section{SimReg1 activates expression of a gusA reporter gene from $\mathrm{P}_{\mathrm{D} 4}$ promoter}

On the basis of the gene inactivation, overexpression and EMSA results we suppose that SimReg1 is a positive regulator of simocyclinone production. To investigate whether SimReg1 can activate the expression of the structural genes under heterologous conditions, a reporter system on the basis of gusA was used. For these purpose, we constructed two plasmids pSimD4script and pUWLsimReg1 (Table 1). In the first plasmid the promoter region of the putative ketoreductase gene simD4 $\left(\mathrm{P}_{D 4}\right)$ was fused with the coding sequence of the gusA gene. As a result expression of the reporter gus $A$ is controlled by $\mathrm{P}_{D 4}$. In the plasmid pUWLsimReg1 intact gene simReg1 was cloned under the control of erythromycin resistance gene promoter to make the expression of the regulatory gene constitutive. As it is evident from the EMSA analysis SimReg1 binds to the promoter of the gene simD4 (Figure 6a) this means that SimReg1 should influence expression from this promoter. To a

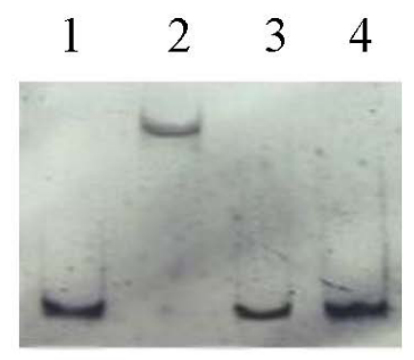

b

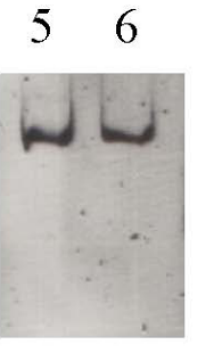

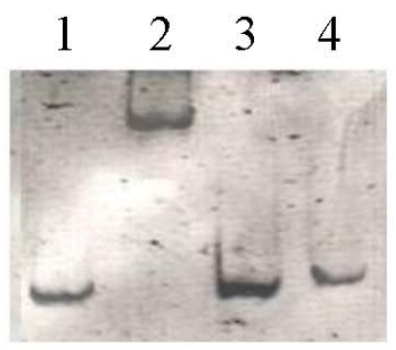

Figure 8 Results of an EMSA performed to investigate the influence of crude extracts from S. antibioticus ü6040 $\times$ pSSimR1-1 strain on the interactions of SimReg1 to promoter regions of the sim cluster. In "a" promoter $P_{R 1}$ and in "b" $P_{A 7}$ were used. (a) lane 1: $P_{R 1} ;$ lane $2: P_{R 1}+$ His-SimReg1; lane 3: $P_{R 1}+$ His-SimReg1 + crude extract isolated from S. antibioticus Tü6040 × pSSimR1-1 (5\% of total reaction volume); lane 4: $P_{R 1}+$ His-SimReg1 + crude extract isolated from S. antibioticus Tü6040 $\times$ pSSimR1-1 (10\% of total reaction volume); lane 5: $P_{R 1}+$ His-SimReg1 + methanol (5\% of total reaction volume); lane 6: $P_{R 1}+$ His-SimReg1 + methanol (10\% of total reaction volume); (b) lane 1: $P_{A 7} ;$ lane 2: $P_{A 7}+$ HisSimReg1; lane 3: $P_{A 7}+$ His-SimReg1 + crude extract isolated from S. antibioticus Tü6040 $\times$ pSSimR1-1 (5\% of total reaction volume); lane 4: $P_{A 7}+$ His-SimReg1 + crude extract isolated from S. antibioticus Tü6040 $\times$ pSSimR1-1 (10\% of total reaction volume) 
verify this assumption, both plasmids were transferred into heterologous host S. lividans 1326 to avoid influence of two other regulatory proteins SimR and SimReg3 Trefzer et al., 2002. We obtained two strains: S. lividans harboring only pSimD4script and S. lividans harboring both plasmids pSimD4script and pUWLsimReg1. As a negative control we used strains: S. lividans $1326 \times$ pGUS to show that there is no GusA activity when gusA gene contains no promoter and S. lividans 1326 harboring both plasmids pGUS (Table 1) and pUWLsimReg1 to demonstrate that SimReg1 specifically binds only to simD4 promoter region and that SimReg1 can't influence gusA expression in the absence of this promoter. Aforementioned four strains were grown in liquid TSB medium for 5 days and samples of the strains were used for GusA activity measurement as described in Materials and Methods. In the control strains the activity of GusA was approximately $0.25 \pm$ 0.06 (Figure 9). In the case of the S. lividans strain that contains gusA gene under $\mathrm{P}_{D 4}$ activity was in average $3.3 \pm 0.24$ (Figure 9). In the strain containing both gusA gene under $\mathrm{P}_{D 4}$ promoter and the SimReg1 protein the activity was $6.25 \pm 0.43$ (Figure 9). It is in overall two times higher than without the protein. On the basis of these results, we may conclude that SimReg1 binds to the $\operatorname{sim} D 4$ promoter region.

\section{Discussion}

Simocyclinone is a potent antibacterial drug that inhibits DNA gyrase supercoiling Oppegard et al. 2009; Sadig et al. 2010; Edwards et al. 2009; Sissi et al. 2009. The gene cluster responsible for simocyclinone production was cloned and biosynthetic, and regulatory genes were detected Trefzer et al. 2002; Galm et al. 2002. Here, we report on the function of the gene simReg1 involved in the regulation of simocyclinone production and export.

SimReg1, to our knowledge, is the first OmpR-PhoB subfamily regulator identified within aminoucoumarin biosynthetic gene clusters. It appears to be a key regulator of simocyclinone production since inactivation of simReg1 completely abolished antibiotic biosynthesis and its overexpression in the wild type strain S. antibioticus Tü6040 led to almost 2.5 times increase in simocyclinone production. In silico analysis and DNA shift assays showed that SimReg1 is a DNA-binding autoregulatory protein that interacts directly with putative promoter regions of the structural sim genes, both transporter genes $\operatorname{sim} X$ and $\operatorname{sim} E x 2$, and the putative regulatory gene simReg3. Our results indicate that SimReg1 is an activator of the structural and transporter genes transcription, as expression of the reporter gene gusA under $\mathrm{P}_{D 4}$ in the presence of SimReg1 was at least two times higher, than without it. DNA-binding activity of SimReg1 is abolished in the presence of extracts from S. antibioticus Tü6040 × pSSimR1-1. As extracts used in the experiment were enriched with simocyclinones, these might indicate the existence of autoregulation by binding most likely simocyclinone or its intermediates. However to establish this assumption additional experiments are required. Similar autoregulation by binding of the end product was described for JadR1 Wang et al. 2009, the close homolog of SimReg1. An interesting finding is that SimReg1 binds to the promoter region of the exporter gene $\operatorname{sim} X$. SimR is known to repress expression of $\operatorname{sim} X$ and its own gene by binding to two distinct operators within the $\operatorname{simR/}$ $\operatorname{sim} X$ intergenic region Le et al. 2009. SimR was shown to dissociate from the $\operatorname{sim} X$ promoter in the presence of simocylinone D8 Le et al. 2009; Le et al. 2011a; Le et al.

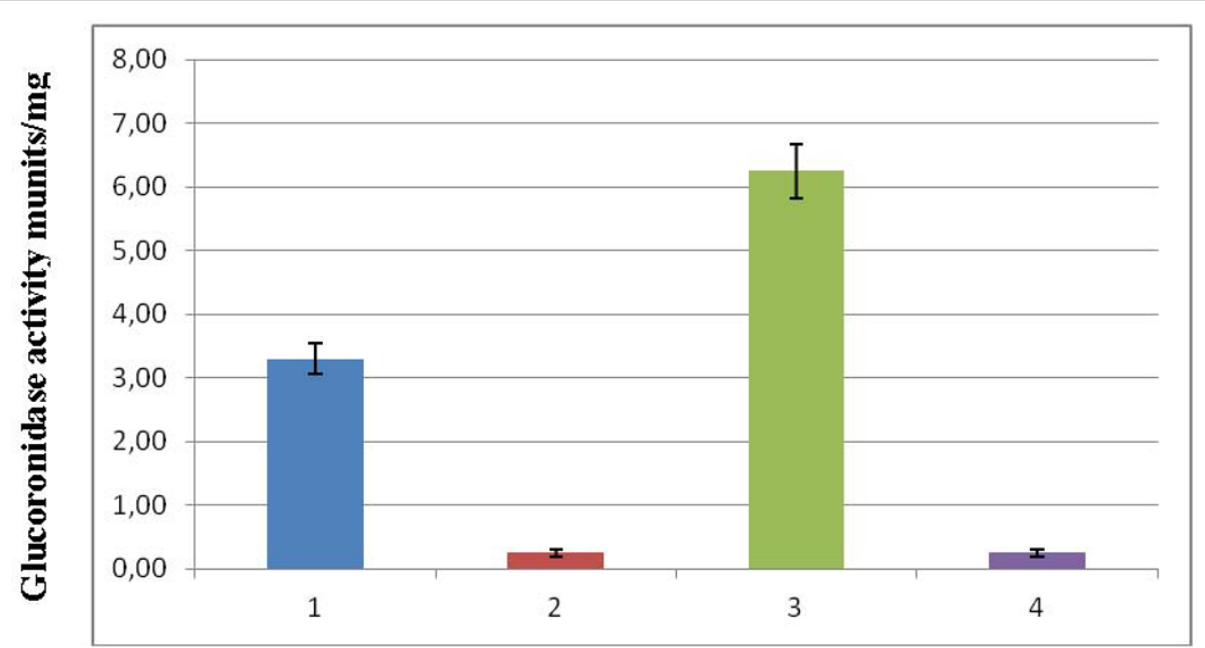

Figure 9 Glucuronidase activity in cell lysates of S. lividans strains: 1 - S. lividansxpSimD4script; 2 - S. lividans×pGUS; 3 - S. lividans $\times$ pSimD4script/pUWLsimReg1; 4 - S. lividans×pGUS/pUWLsimReg1. 
2011b. At the same time SimReg1 is interacting with the 69 bp DNA region upstream to the start codon of $\operatorname{sim} X$. This means that the operator of SimReg2 partially overlaps with the DNA-binding region of SimReg1. Therefore, it is very likely that in the presence of simocyclinone dissociation of SimReg2 from the promoter region of $\operatorname{sim} X$ is necessary for SimReg1 binding indicating that SimReg1 and SimReg2 compete for the binding to the $\operatorname{sim} X$ promoter.

The presence of distinct regulatory proteins indicates the importance for the cell to strongly control simocyclinone production and transport. The structure of simocyclinone is assembled from products of three distinct biosynthetic routes. To produce such a complex molecule the biosynthetic pathway and the transport have to be precisely tuned and controlled.

Based on our data and the data described by Buttner and coworkers Le et al. 2009; Le et al. 2011a; Le et al. 2011b, we proposed the following preliminary model for the regulation of simocyclinone biosynthesis and export. When the concentration of simocyclinone and/or its intermediates is low the transcription of the exporter gene $\operatorname{sim} X$ is repressed by SimR. At the same time, SimReg1, being the key regulator of simocyclinone biosynthesis, activates expression of the structural sim-genes and simocyclinone production. When the cellular concentration of simocyclinone exceeds a certain level, SimR is released from $P_{S E x 1}$ that allows SimReg1 to bind to the promoter. This activates $\operatorname{sim} X$ expression, followed by the transport of simocyclinones out of the cell. This mechanism couples the biosynthesis of simocyclinone to its export. In such a way, an additional mechanism of exact tuning of biosynthesis level is exerted ensuring the protection of the producing bacteria from the toxicity of its secondary metabolism product.

The present study portrays a strong link between antibiotic production and export and describes for the first time the function of the atypical response regulator in the control of the biosynthesis of simocyclinone. Furthermore, our data suggest a useful biotechnological approach for optimization of simocyclinone production, as overexpression the gene encoding positive regulator SimReg1 leads to antibiotic overproduction.

\section{Additional material}

Additional file 1: HPLC analysis of secondary metabolites produced by $S$. antibioticus Tü6040 $\times$ pSSimR1-1. On axis y relative absorption units $(A U)$ are plotted. On axis $x$ retention time of compounds is plotted (in min). Under conditions stated SD8 has $R_{t}$ of $24.7 \mathrm{~min}$. The overall content of simocyclinones in the extract was around of $95 \%$.

Additional file 2: Purification of the His-tagged SimReg1 protein from E. coli BL21 (DE3). Lane 1: molecular mass marker (Pierce Protein Research Products); lane 2: flow through; lane 3: purified SimReg1.
Additional file 3: Results of EMSA performed to detect interactions of SimReg1 to part of the simD4 gene. Lane 1: simD4; lane 2: simD4 + His-SimReg1; lane 3: simD4 + His-SimReg1; lane 4: simD4 + His-SimReg1.

\section{Acknowledgements}

This work was supported by the DAAD, grant to L.H. (PKZ A/07/99406) and by the BMBF (grant to A.B.)

\section{Author details}

${ }^{1}$ Department of Genetics and Biotechnology of Ivan Franko National University of L'viv, Grushevskogo st.4, L'viv 79005, Ukraine ${ }^{2}$ HelmholtzInstitute for Pharmaceutical Research Saarland (HIPS), Helmholtz Center for Infectious Research (HZI), Department Microbial Natural Products Actinobacteria, Metabolic Engineering Group, Saarland University, Campus C2 366123 Saarbrücken, Germany ${ }^{3}$ Institut für Pharmazeutische Wissenschaften, Lehrstuhl für Pharmazeutische Biologie und Biotechnologie, Albert-Ludwigs-Universität Freiburg, Stefan-Meier-Strasse 19, 79104 Freiburg, Germany

\section{Competing interests}

The authors declare that they have no competing interests.

Received: 21 November 2011 Accepted: 3 January 2012

Published: 3 January 2012

\section{References}

Arias P, Miguel A, Férnandez-Moreno A, Malpartida F (1999) Characterization of the Pathway-Specific Positive Transcriptional Regulator for Actinorhodin Biosynthesis in Streptomyces coelicolor A3(2) as a DNA-Binding Protein. J Bacteriol 181:6958-6968

Bibb M, Hesketh A (2009) Analyzing the regulation of antibiotic production in Streptomyces. Method Enzymol 458:93-116

Bierman M, Logan R, O'Brein K, Seno E, Rao R, Schoner B (1992) Plasmid cloning vectors for the conjugal transfer of DNA from Escherichia coli to Streptomyces spp. Gene 116:43-49. doi:10.1016/0378-1119(92)90627-2.

Blondelet-Rouault M-H, Weiser Y, Lebrihi A, Branny P, Pernodet JL (1997) Antibiotic resistance gene cassettes derived from the $U^{\prime}$ interposon for use in Escherichia coli and Streptomyces. Gene 190:315-317. doi:10.1016/S0378-1119 (97)00014-0.

Chen L, Lu Y, Chen J, Zhang W, Shu D, Qin Z, Yang S, Jiang W (2008) Characterization of a negative regulator Avel for avermectin biosynthesis in Streptomyces avermitilis NRRL8165. Appl Microbiol Biotechnol 80:277-286. doi:10.1007/s00253-008-1545-8.

Dyer CM, Dahlquist FW (2006) Switched or not: the structure of unphosphorylated CheY bound to the $\mathrm{N}$ terminus of FliM. J Bacteriol 188:7354-7363. doi:10.1128/JB.00637-06.

Edwards MJ, Flatman RH, Mitchenall LA, Stevenson CE, Le TB, Clarke TA, McKay AR, Fiedler H-P, Buttner MJ, Lawson DM, Maxwell A (2009) A crystal structure of the bifunctional antibiotic simocyclinone D8, bound to DNA gyrase. Science 326:1415-1458. doi:10.1126/science.1179123.

Flett F, Mersinias V, Smith C (1997) High efficiency intergeneric conjugal transfer of plasmid DNA from Escherichia coli to methyl DNA-restricting Streptomyces. FEMS Microbiol Lett 155:223-229. doi:10.1111/j.1574-6968.1997.tb13882.x.

Galm U, Schimana J, Fiedler H-P, Schmidt J, Li SM, Heide L (2002) Cloning and analysis of the simocyclinone biosynthetic gene cluster of Streptomyces antibioticus Tü6040. Arch Microbiol 178:102-114. doi:10.1007/s00203-0020429-z.

Hanahan D (1985) Techniques for transformation of Escherichia coli. In: Glover DM (ed) DNA Cloning. Oxford, UK: IRL Press pp 109-135

Hopwood DA, Bibb MJ, Chater KF, Kieser T, Bruton CJ, Kieser HM, Lydiate DJ, Smith CP, Ward JM, Schrempf H (1985) Genetic manipulation of streptomyces: A laboratory manual. Norwich: The John Innes Foundation

Hopwood DA (2007) How do antibiotic-producing bacteria ensure their selfresistance before antibiotic biosynthesis incapacitates them? Mol Microbiol 63:937-940. doi:10.1111/j.1365-2958.2006.05584.x.

Horinouchi S (2007) Mining and polishing of the treasure trove in the bacterial genus Streptomyce. Biosci Biotechnol Biochem 71:283-299. doi:10.1271/ bbb.60627. 
Hsiao N-H, Gottelt M, Takano E (2009) Regulation of antibiotic production by bacterial hormones. Meth Enzymol 458:143-157

Kieser T, Bibb MJ, Buttner MJ, Chater KF, Hopwood DA (2000) Practical Streptomyces genetics. The John Innes Foundation, Norwich

Le TB, Fiedler H-P, den Hengst CD, Ahn SK, Maxwell A, Buttner MJ (2009) Coupling of the biosynthesis and export of the DNA gyrase inhibitor simocyclinone in Streptomyces antibioticus. Mol Microbiol 72:1462-1474. doi:10.1111/j.1365-2958.2009.06735.x.

Le TB, Stevenson CE, Buttner MJ, Lawson DM (2011) Crystallization and preliminary X-ray analysis of the TetR-like efflux pump regulator SimR. Acta Crystallogr Sect Struct Biol Cryst Commun 67:307-309. doi:10.1107/ S1744309110053078.

Le TB, Stevensoc CE, Fiedler H-P, Maxwell A, Lawson DM, Buttner MJ (2011) Structures of the TetR-like Simocyclinone Efflux Pump Repressor, SimR, and the Mechanism of Ligand-Mediated Derepression. J Mol Biol 408:40-56. doi:10.1016/j.jmb.2011.02.035.

Luzhetskyy A, Fedoryshyn M, Gromyko O, Ostash B, Rebets Y, Bechthold A, Fedorenko V (2006) IncP plasmids are most effective in mediating conjugation between Escherichia coli and Streptomyces. Genetica 42:595-601

Muth G, Nussbaumer B, Wohlleben W, Pühler A (1989) A vector system with temperature-sensitive replication for gene disruption and mutational cloning in streptomycetes. Mol Gen Genet 6:1-8

Myronovskyi M, Welle E, Fedorenko V, Luzhetskyy A (2011) $\beta$-Glucuronidase as a sensitive and versatile reporter in actinomycetes. Appl Environ Microbiol 77:5370-5383. doi:10.1128/AEM.00434-11.

Novakova R, Rehakova A, Feckova L, Kutas P, Knischova R, Kormanec J (2011) Genetic manipulation of pathway regulation for overproduction of angucycline-like antibiotic auricin in Streptomyces aureofaciens CCM 3239. Folia Microbiol 56:276-282. doi:10.1007/s12223-011-0033-1.

Nuria A, Santos-Aberturas J, Mendes M, Guerra S, Martin J, Aparacio J (2007) PimM, a PAS domain positive regulator of pimaricin biosynthesis in Streptomyces natalensis. J Bacteriol 153:3174-3183

Ohnishi Y, Ishikawa J, Hara H, Suzuki H, Ikenoya M, Ikeda H, Yamashita A, Hattori M, Horinouchi S (2008) Genome sequence of the streptomycinproducing microorganism Streptomyces griseus IFO 13350. J Bacteriol 1904:4050-4060

Oppegard LM, Hamann BL, Streck KR, Ellis KC, Khodursky AB, Hiasa H (2009) In vivo and in vitro patterns of the activity of simocyclinone D8, an angucyclinone antibiotic from Streptomyces antibioticus. Antimicrob Agents Chemother 53:2110-2119. doi:10.1128/AAC.01440-08.

O'Rourke S, Wietzorrek A, Fowler K, Corre C, Challis G, Chater K (2009) Extracellular signaling, translational control two repressors and an activator all contribute to the regulation of methylenomycin production in Streptomyces coelicolor. Mol Microbiol 71:763-778. doi:10.1111/j.1365-2958.2008.06560.x.

Ostash I, Ostash B, Luzhetskyy A, Bechthold A, Walker S, Fedorenko V (2008) Coordination of export and glycosylation of landomycins in Streptomyces cyanogenus S136. FEMS Microbiol Lett 285:195-202. doi:10.1111/j.15746968.2008.01225.x

Ostash B, Rix U, Rix LL, Liu T, Lombo F, Luzhetskyy A, Gromyko O, Wang C, Bran̆a AF, Méndez C, Salas JA, Fedorenko V, Rohr J (2004) Generation of new landomycins by combinatorial biosynthetic manipulation of the IndGT4 gene of the landomycin E cluster in S. globisporus. Chem Biol 11:547-555. doi:10.1016/j.chembiol.2004.03.011.

Pulsawat N, Kitani S, Nihira T (2007) Characterization of the biosynthetic gene cluster for the production of virginiamycin M, a streptogramin type A antibiotic, in Streptomyces virginiae. Gene 393:31-42. doi:10.1016/j. gene.2006.12.035.

Rebets Y, Ostash B, Luzhetskyy A, Hoffmeister D, Brana A, Mendez C, Salas JA, Bechthold A, Fedorenko V (2003) Production of landomycins in strains Streptomyces globisporus 1912 and S. cyanogenus S136 is regulated by genes encoding putative transcriptional activators. FEMS Microbiol Lett 222:149-153. doi:10.1016/S0378-1097(03)00258-1.

Rebets Y, Ostash B, Luzhetskyy A, Kushnir S, Fukuhara M, Bechthold A, Nashimoto M, Nakamura T, Fedorenko V (2005) DNA-binding activity of Lndl protein and temporal expression of the gene that upregulates landomycin $\mathrm{E}$ production in Streptomyces globisporus 1912. Microbiol 151:281-290. doi:10.1099/mic.0.27244-0.

Rebets Y, Dutko L, Ostash B, Luzhetskyy A, Kulachkovskyy O, Yamaguchi T, Nakamura T, Bechthold A, Fedorenko V (2008) Function of lanl gene in regulation of landomycin A biosynthesis in Streptomyces cyanogenus S136 and cross-complementation studies of streptomyces antibiotic regulatory proteins encoding genes. Archives of Microbiol 189:111-120. doi:10.1007/ s00203-007-0299-5.

Ruiz D, Salinas P, Lopez-Redondo ML, Cayuela M, Marina A, Contreras A (2008) Phosphorylation-independent activation of the atypical response regulator NblR. Microbiol 154:3002-3001. doi:10.1099/mic.0.2008/020677-0.

Sadig A, Patel M, Jacobson B, Escobedo M, Ellis K, Oppegard L, Hiasa H, Kratzke R (2010) Anti-proliferative effects of simocyclinone D8 (SD8), a novel catalytic inhibitor of topoisomerase II. Invest New Drugs 28:20-25. doi:10.1007/s10637008-9209-1.

Sambrook J, Russell D (2001) Molecular cloning, a laboratory manual. Cold Spring Harbor Laboratory, 3rd edn.Cold Spring Harbor, NY

Schimana J, Walker M, Zeeck A, Fiedler H-P (2001) Simocyclinones: diversity of metabolites is dependent on fermentation conditions. J Ind Microbiol Biotechnol 27:144-148. doi:10.1038/s.j.jim.7000024.

Sheldon P, Busarow S, Hutchinson R (2002) Mapping the DNA-binding domain and target sequences of the Streptomyces peucetius daunorubicin biosynthesis regulatory protein, Dnrl. Mol Microbiol 44:449-460. doi:10.1046/ j.1365-2958.2002.02886.x.

Sissi C, Vazquez E, Chemello A, Mitchenall LA, Maxwell A, Palumbo M (2009) Mapping simocyclinone D8 interaction with DNA gyrase: evidence for a new binding site on GyrB. Antimicrob Agents Chemother 54:213-220

Sola-Landa A, Moura RS, Martin J (2003) The two-component PhoR-PhoP system controls both primary metabolism and secondary metabolite biosynthesis in Streptomyces lividans. PNAS 100:6133-6138. doi:10.1073/pnas.0931429100.

Tahlan K, Ahn S, Sing A, Bodnaruk T, Willems A, Davidson A, Nodwell J (2007) Initiation of actinorhodin export in Streptomyces coelicolor. Mol Microbiol 63:951-961. doi:10.1111/j.1365-2958.2006.05559.x.

Trefzer A, Pelzer S, Schimana J, Stockert S, Bihlmaier C, Fiedler H-P, Welzer K, Vente A, Bechthold A (2002) Biosynthetic gene cluster of simocyclinone, a natural multihybrid antibiotic. Antimicrobial Agents and Chemoth 46:1174-1182. doi:10.1128/AAC.46.5.1174-1182.2002.

van Wezel GP, McKenzie N, Nodwell J (2009) Applying the genetics of secondary metabolism in model actinomycetes to the discovery of novel antibiotics. Methods Enzym 458:118-134

van Wezel PGilles, McDowall JKenneth (2011) The regulation of the secondary metabolism of Streptomyces: new links and experimental advances. Nat Prod Rep 28:1311-1333. doi:10.1039/c1np00003a.

Wang L, Tian X, Wang J, Yang H, Fan K, Xu G, Yang K, Tan H (2009) Autoregulation of antibiotic biosynthesis by binding of the end product to an atypical response regulator. PNAS 106:8617-8622. doi:10.1073/ pnas.0900592106.

Zelyas N, Tahlan K, Jensen S (2009) Use of the native flp gene to generate inframe unmarked mutations in Streptomyces spp. Gene 443:48-54. doi:10.1016/j.gene.2009.03.022.

\section{doi:10.1186/2191-0855-2-1}

Cite this article as: Horbal et al: SimReg1 is a master switch for biosynthesis and export of simocyclinone D8 and its precursors. $A M B$ Express 2012 2:1.

\section{Submit your manuscript to a SpringerOpen ${ }^{\mathcal{O}}$ journal and benefit from:}

- Convenient online submission

- Rigorous peer review

- Immediate publication on acceptance

- Open access: articles freely available online

- High visibility within the field

- Retaining the copyright to your article

Submit your next manuscript at $\boldsymbol{\nabla}$ springeropen.com 